\title{
Study of Land Use Change for Preparation of Watershed Management Planning
}

\author{
Latief Mahir Rachman* \\ Department of Soil Science and Land Resource, \\ Faculty of Agriculture, IPB University, \\ Bogor, Indonesia \\ Yayat Hidayat \\ Department of Soil Science and Land Resource, \\ Faculty of Agriculture, IPB University, \\ Bogor, Indonesia
}

\author{
Dede Sulaeman \\ World Research Institute, Jakarta, Indonesia
}

\begin{abstract}
In an integrated approach, watershed management crucially needed to maintain condition and quality of watershed. Land use change is one of main causes of watershed condition and quality changing. Therefore, it required planning alternatives suggestions to prevent and recover the watershed degradation. The research was carried out to study about watershed changes and degradation due to land use change and investigating for the best alternative to restore Ciujung Watershed, Banten, Indonesia using Soil and Water Assessment Tool (SWAT) model. Research result showed that the reduced of forest area (plantation forest, primary dryland forest, secondary dryland forest) and the increased of dryland agricultural, dryland mixed farming (mixed with bush, plantation, rice fields and bushes) caused the increase of river flow. Several alternative soil and water conservation techniques as if reforestation, agroforestry, strip cropping, contour cropping, dam building and the application of bio-retention hole could be done for land management to maintain and improve the condition and quality of Ciujung Watershed which is indicated by a decrease in values of River Regime Coefficient (RRC), surface runoff coefficient, and sediment yield.
\end{abstract}

Keywords: Annual Flow Coefficient (AFC), land use change, RRC, Soil and Water Assessment Tool (SWAT) model, watershed management

Received: 12 August 2019; Accepted: 20 September 2019; Published: 25 November 2019

\section{INTRODUCTION}

Land use and changes are largely determined the conditions and quality changes in a watershed. The decreased of forest area and the land use changes which not following by soil and water conservation method will reduce soil capacity in absorbing water and increased surfaced flow, erosion, and sediment discharge [1,2] and finally reduce and worsen the quality of watershed. Several studies stated that cutting of forest area or deforestation changed the ground water balance, decreased the river discharge and, underground water reserves, and also the supply of water resources in semiarid and sub-humid areas (Huang et al., Zou et al., as cited in [3]).

Watershed quality received enormous attention and increased being considered and used in regional planning since the quality of a watershed greatly determines productivity of areas, environmental pollution and also controls a role on services and environments in an area, especially related to clean water supply $[4,5,6]$.

According to [7], watershed management in an in-

\footnotetext{
${ }^{*}$ Correspondence concerning this article should be addressed to Latief Mahir Rachman, Department of Soil Science and Land Resource, Faculty of Agriculture, IPB University, Bogor, Indonesia. E-mail: gpgempes@gmail.com

(c) 2019 The Author(s). Published by KKG Publications. This is an Open Access article distributed under a Creative Commons AttributionNonCommercial-NoDerivatives 4.0 International License.
} 
tegrated approach is harmonization or synchronization development purposes from every natural resource management system. Based on congenial and balance preservation of environmental capabilities to support sustainable development towards the improvement of human welfare, watershed management implemented through utilization, arrangement, preservation, observation, management, restoration, and development of a watershed. Principle of resource conservations and environmental capability refer to the consideration of productivity and resource conservations to attain some purposes. To maintain watershed sustainability, the stability of ecosystem needs to be preserved in order to maintain watershed components in a good and optimal interrelationship.

Ciujung Watershed included into the widest watershed in Banten Province, Indonesia, yet the quality is getting worse. The main cause is presumably due to the pressure of increasing population and decreasing forest area because of the forest area conversion which becomes agriculture area and the changes of agriculture area which becomes residential area. The degradation of Ciujung watershed quality shown by the increasing of the frequency and widespread flooding, drought matters during the dry season, the increasing of AFC, RRC and sediment discharge also the decreasing of water yield and ground water.

The improvement of Ciujung Watershed quality through various soil and water conservation techniques need to be done. Soil conservation is the placement of a plot of land according to its ability and treated by providing necessary conditions so there will be no damage to the soil. Meanwhile, water conservation is an effort to preserve the water in the soil, so the rainwater could be entered into the soil and restrained, then the water in the soil can be used during the dry season [8]. Soil and water conservation to improve watershed quality can be served through vegetative, chemical, and mechanical or technical civil methods. The combination among soil and water conservation method, vegetative, chemical, and mechanical methods could improve watershed quality effectively [9].

SWAT is a hydrological watershed scale model which has been used extensively throughout the world for various purposes [10,11], such as predicting the condition of watershed hydrology referring to the land use change, ap- plying soil and water conservation techniques, and global climate changes, modeling the changes of soil and climate usability [12] and the effect of conservation on water quality $[13,14]$, evaluating different agriculture management strategies [15], and helping to plan the preparation of watershed management (Storm et al., as cited in [3]).

The research was carried out to study about watershed quality changes and degradation due to land use change and investigating for the best alternative to restore Ciujung Watershed, Banten, Indonesia by using SWAT method.

\section{MATERIALS AND METHODOLOGY}

\section{A. Time and Location}

The research was carried out from February to December 2014 in the Ciujung Watershed Area, located at 5 $5^{\circ} 57^{\prime} 14^{\prime \prime}-5^{\circ} 57^{\prime} 14^{\prime \prime}$ SL and $106^{\circ} 01^{\prime} 00^{\prime \prime}-106^{\circ} 29^{\prime} 03^{\prime \prime}$ EL with $\pm 190.635,6$ ha which administratively include into Lebak District, Pandeglang District, Serang District, Serang City, Banten Province and Bogor District, West Java Province, Indonesia.

\section{B. Materials and Tool}

The important material which the researcher used is secondary data, especially rainfall and daily river flow discharge data from 2001 to 2012; daily sediment discharge data from February to December 2013; climate data maximum and minimum temperatures, wind velocity, air humidity and solar radiation; Land Use Map with 1:250.000 scale from Forest Planology Agency (FPA); Land Unit Map with 1:250.000 scale from Indonesian for Center for Agricultural Land Resource (ICALR); and Digital Elevation Model (DEM) Map with 30 meter resolution from Geospatial Information Agency (GIA).

The most important tools are: 1) a set of computer with ArcGIS 10.1 software and ArcSWAT 2012 as an interface, pcpSTAT, SWAT Plot, SWAT BFlow, and SWAT CUP, 2) Global Positioning System (GPS), 3) ring sample, 4) double ring infiltrometer, and 5) equipment to analyze the soil physical properties in the laboratory related to this research.

\section{Research Methodology}

Methods that the researcher used in this research presented in the Table 1. 
TABLE 1

THE METHODS USED FOR VARIOUS ASPECTS/FACTORS

Aspect/Factors Method Information/Formula

Secondary Data Secondary data collection trough several related institutes/agencies

Soil Sampling and Analysis

Rainfall Analysis

Runoff (RO) Analysis of River Flow

Watershed Area Condition Analysis

Land Use Change Analysis

SWAT Model Development

WAT Model Calibration
Infiltration rate with the double ring infiltrometer method Soil permeability (constant head method) Content density (gravimetric method) Water availability (pressure plate and membrane apparatus method) Organic carbon (Walkey and Black method) Soil textures (pipette method)

The average rainfall $(\mathrm{P})$ is calculated using Thiessen method

$\mathrm{RO}$ is stated in the thickness unit $(\mathrm{mm})$

$\mathrm{AFC}-\mathrm{RRC}=$ maximum discharge ratio $\left(\mathrm{Q}_{\max }\right) /$ minimum discharge $\left(\mathrm{Q}_{\min }\right)$

Processing by inserting Pivot table in the Microsoft Excel

Process Series: Data preparation, watershed area delineation, HRU analysis, climate input data, construct input data, and testing run SWAT model which has constructed

Determination coefficient model $\left(\mathrm{R}^{2}\right)$ and NSE efficiency model
Especially Water Resource Management Center (WRMC) of Ciujung-Cidanau, River Basin Centre of Ciujung-Cidanau-Ciasadane, Meteorology Climatology and Geophysics Council, Class I Serang, Watershed Management Office of Citarum-Ciliwung, ICALR,FPA, and GIA

Field soil observation was carried out to identify the effective soil depth, of rock composition (\%) in the topsoil and to measure the infiltration rate Soil sampling for analysis of the soil bulk density, soil texture, organic carbon content, soil permeability and water availability

$P=\frac{\left(A_{1} \times P_{1}\right)+\left(A_{2} \times P_{2}\right)+\ldots \ldots .+\left(A_{n} \times P_{n}\right)}{\sum A}$

$A_{n}=$ area of each polygon

$P_{n}=$ rainfall of each station

$\mathrm{RO}=\frac{\text { Debit }\left(\mathrm{m}^{3} / \text { second }\right)^{*} \sum \text { days } * 86400 \text { seconds }}{\text { DAS area }\left(\mathrm{m}^{2}\right)}$

- $\mathrm{AFC}=$ total runoff $(\mathrm{mm}) /$ total rainfall $(\mathrm{mm})$

- AFC $\leq 0.2$ very low

$0.2<\mathrm{AFC} \leq 0.3$ low

$0.3<\mathrm{AFC} \leq 0.4$ medium

$0.4<\mathrm{AFC} \leq 0.5$ high

$\mathrm{AFC}>0.5$ very high

- RRC = Qmax/Qmin

- score RRC $\leq 20$ very low;

$20 \leq \mathrm{RRC} \leq 50$ low;

$50 \leq \mathrm{RRC} \leq 80$ medium;

$80 \leq \mathrm{RRC} \leq 110$ high;

dan $R R C \geq 110$ very high

Using Land Use Map with 1:250.000 scale from FPA

Watershed Area Digitation using DEM map

- For $\mathrm{R}^{2}$, score $\mathrm{R}^{2} \geq 0.5$ can be accepted

- For NSE Clarification Score*: score NSE $\leq 0.5$ unsatisfactory; 
TABLE 1 CONTINUE

Aspect/Factors Method Information/Formula

$0.50 \leq \mathrm{NSE} \leq 0.65$ satisfying;

$0.65 \leq \mathrm{NSE} \leq 0.75$ good, and

$0.75 \leq \mathrm{NSE} \leq 1.00$ very good

SWAT Model Vali- Determination coefficient model

- For $\mathrm{R}^{2}$, score $\mathrm{R}^{2} \geq 0.5$ can be accepted

dation

$\left(\mathrm{R}^{2}\right)$ and NSE efficiency model

- For NSE Clarification Score*:

score NSE $\leq 0.5$ unsatisfactory;

$0.50 \leq \mathrm{NSE} \leq 0.65$ satisfying;

$0.65 \leq \mathrm{NSE} \leq 0.75$ good, and

$0.75 \leq \mathrm{NSE} \leq 1.00$ very good

NSE $=$ Nash-Sutcliffe Efficiency (Moriasi, et al., as cited in the [16]

D. The Use of Scenario

In the simulation to choose the best alternative for

Ciujung Watershed Area improvement, 5 (five) scenarios was applied. The description from five scenarios along with their area presented in the Table 2.

TABLE 2

PROJECTED LAND MANAGEMENT TYPES AND SOIL AND WATER CONSERVATION TECHNIQUES FROM THE FIVE SCENARIOS ALONG WITH SIMULATED HYDROLOGICAL PARAMETERS AND EXTENT OF IMPROVEMENT

\begin{tabular}{|c|c|c|c|c|c|}
\hline \multirow[t]{2}{*}{ Scenario } & \multirow[t]{2}{*}{ Land Management Types } & \multirow{2}{*}{$\begin{array}{l}\text { Soil and Water Conservation } \\
\text { Techniques }\end{array}$} & \multirow{2}{*}{$\begin{array}{l}\text { Simulated Hydrological Parame- } \\
\text { ters }\end{array}$} & \multicolumn{2}{|c|}{ Area } \\
\hline & & & & $\mathrm{Ha}$ & $\%$ \\
\hline 1 & $\begin{array}{l}\text { Application of Forest Area } \\
\text { Functions }\end{array}$ & Reforestation & CN2, SOL_K, SOL_C, SOL_BD & 17,333 & 12 \\
\hline 3 & $\begin{array}{l}\text { Soil and Water Conser- } \\
\text { vation using Vegetative } \\
\text { Method }\end{array}$ & $\begin{array}{l}\text { Reforestation } \\
\text { Agroforestry Strip cropping }\end{array}$ & $\begin{array}{l}\text { CN2, SOL_K, SOL_C, SOL_BD, } \\
\text { SOL_AWC CN2, SOL_K, } \\
\text { SOL_C, SOL_BD STRIP_CN, } \\
\text { STRIP_P, STRIP_C, STRIP_N }\end{array}$ & 40,202 & 28 \\
\hline 5 & $\begin{array}{l}\text { Combination of Scenarios } \\
1,2,3,4\end{array}$ & $\begin{array}{l}\text { Reforestation Agroforestry } \\
\text { Strip cropping } \\
\text { Water Dam Contour Planting } \\
\text { BIH }\end{array}$ & $\begin{array}{l}\text { CN2, SOL_K, SOL_C, SOL_BD, } \\
\text { SOL_AWC CN2, SOL_K, } \\
\text { SOL_C, SOL_BD STRIP_CN, } \\
\text { STRIP_P, STRIP_C, STRIP_N } \\
\text { RES_VOL,RES_EVOL, } \\
\text { RES_PVOL CONT_P, } \\
\text { CONT_CN SOL_BD, SOL_K }\end{array}$ & 66,390 & 47 \\
\hline $\begin{array}{l}\text { Remarks: } \mathrm{B} \text { - } \\
\text { slightly criti } \\
\text { CN2 = curve } \\
\text { content; STH } \\
\text { cropping; S } \\
\text { RES_VOL = }\end{array}$ & $\begin{array}{l}=\text { Bio-pore Infiltration Holes; } * \text { I } \\
\text { land on dry land agriculture, } \mathrm{d}_{1} \\
\text { umber; SOL_K = soil permeabi } \\
\text { ICN }=\text { surface flow curve num } \\
\text { IP_C = crop factor values }(\mathrm{C} U \\
\text { am volume; RES_EVOL }=\text { eme }\end{array}$ & $\begin{array}{l}\text { lity; SOL_C = soil organic matter; } \\
\text { bers for cropping strips; STRIP_P = } \\
\text { SLE) for cropping strips; STRIP_N } \\
\text { gency spillway; RES_PVOL = prin }\end{array}$ & $\begin{array}{l}\text { all land uses (except the settlement) and ag } \\
\text { atations and shrubs. } \\
\text { OL_BD = soil bulk density; SOL_AWC = } \\
\text { he value of the land management factor ( } \\
\text { Manning roughness coefficient values for } \\
\text { pal spillway; CONT_P = the value of the }\end{array}$ & $\begin{array}{l}\text { available } \\
\text { USLE) } 1 \\
\text { cropping } \\
\text { and mana }\end{array}$ & $\begin{array}{l}\text { for a } \\
\text { ater } \\
\text { strip } \\
\text { rips; } \\
\text { ment }\end{array}$ \\
\hline
\end{tabular}




\section{E. Setting and Calculating Scenario Scored}

To calculate every scenario scores, percent classification change is carried out and can be seen on the Table 3.

TABLE 3

SCORE SETTING FOR EVERY PRESENT CHANGE RANGE CLASS

\begin{tabular}{llllll}
\hline Change Range & $<20 \%$ & $20 \%-40 \%$ & $40 \%-60 \%$ & $60 \%-80 \%$ & $>80 \%$ \\
\hline Score & 1 & 2 & 3 & 4 & 5 \\
\hline
\end{tabular}

\section{RESULTS AND DISCUSSION}

For five years from 2006 to 2011, it is estimated that there has been a reduction in a forest area due the conversion of forest area to agricultural land, such as dry land farming mixed with bush, dry land farming, and rice fields. Application of soil and water conservation techniques in agricultural areas is very limited, perhaps it becomes the main cause which causes the quality of Ciujung Watershed getting worsen.

TABLE 4

LAND USE CHANGE OF CIUJUNG WATERSHED IN 5 YEARS (FROM 2006 TO 2011)

\begin{tabular}{llllll}
\multirow{2}{*}{ No } & Land Use & 2006 & 2011 & \multicolumn{2}{c}{ Changes } \\
\cline { 3 - 5 } & & $($ ha) & (ha) & (ha) & $\%$ \\
\hline & & & & & \\
1 & Primary Dryland Forest & $1.937,4$ & $1.924,0$ & $-13,4$ & 0,0007 \\
2 & Secondary Dryland Forest & $8.845,6$ & $8.642,7$ & $-202,9$ & 0,0106 \\
3 & Tree Plantations & $21.217,2$ & $18.268,9$ & $-2.948,3$ & 0,1547 \\
4 & Settlement & $5.615,9$ & $5.615,9$ & 0,0 & 0,0000 \\
5 & Plantation & $13.023,9$ & $13.123,1$ & 99,2 & 0,0052 \\
6 & Dryland Farming & $23.934,4$ & $24.097,9$ & 163,5 & 0,0086 \\
7 & Dryland Farming Mixed with Bush & $60.702,9$ & $62.673,3$ & $1.970,4$ & 0,1034 \\
8 & Rice Fields & $45.546,7$ & $46.244,3$ & 697,5 & 0,0366 \\
9 & Shrubs & $8.633,1$ & $8.858,4$ & 225,3 & 0,0118 \\
10 & Open Field & 675,5 & 684,2 & 8,7 & 0,0005 \\
11 & Water Body & 503,0 & 503,0 & 0,0 & 0,0000 \\
& Total & $190.635,6$ & $190.635,6$ & & \\
\hline
\end{tabular}

Area reductions occurred in the tree plantations which reduced 2.948,3 ha area or 0,1547 percent from total Ciujung Watershed area, secondary dryland forest reduction for about 202,9 ha area or 0,0106 percent and primary dryland forest which reduced 13,4 ha area or 0,0007 percent. Meanwhile, the largest increase occurred in agricultural and plantation area, which is dryland farming mixed with bush about 1.970,4 ha or 0,1034 percent from total Ciujung Watershed area, following by 697,5 ha rice fields or 0.0366 percent; shrubs with 225,3 ha area or 0,0118 percent; dryland farming about 163,5 ha or 0,0086 percent and plantation which has 99,2 ha area or 0,0052 percent.

The readiness SWAT Model which prepared for simulation to compare the effective results from every scenario in order to improve watershed quality through several parameters or indicators is very determined from the re- sults of the calibration and validation of the SWAT model which has been built.

The result of SWAT calibration model gave $R^{2}$ and NSE scores, for each 0,78 and 0,67 (categorized as good score). While the results of $R^{2}$ and NSE in validation process were 0,75 and 0,67 (categorized as good score). Those scores are already having a higher score from the criteria for a model which can do simulation process in modeling [17].

A worse Ciujung Watershed condition showed by several watershed quality indicators, especially AFC about $31 \%, \mathrm{RRC}$ or $\mathrm{Q}_{\max }-\mathrm{Q}_{\min }$ ratio about 198 along with sediment discharge about 47.966 tons per day.

Ciujung Watershed quality improvement could be done by applying proper and/or compatible soil and water conservation techniques. Five scenarios simulation, soil 
and water conservation techniques which suggested as described below, gave variation results in the improvement of several hydrological parameters which are often used to assess watershed quality.

Simulation results from five scenarios through hydrology parameters in Ciujung Watershed can be seen on
Table 5. Five scenarios show the variations, the difference in decreasing the surface flow, AFC, sediment discharge, maximum discharge $\left(\mathrm{Q}_{\max }\right)$, and $\mathrm{RRC}$ also the increasing of minimum discharge $\left(\mathrm{Q}_{\min }\right)$ and the water ground (except scenario 3 ).

TABLE 5

SCENARIO SIMULATION RESULT TOWARD HYDROLOGY PARAMETERS IN CIUJUNG WATERSHED AREA

\begin{tabular}{|c|c|c|c|c|c|c|c|c|c|c|c|c|c|c|}
\hline \multirow[t]{2}{*}{ Scenario } & \multirow{2}{*}{$\begin{array}{l}\text { Rainfall } \\
(\mathrm{mm})\end{array}$} & \multicolumn{3}{|c|}{ Surface Flow } & \multicolumn{2}{|c|}{ Sediment Discharge } & \multicolumn{2}{|c|}{$\mathrm{Q}_{\max }$} & \multicolumn{2}{|c|}{$\mathrm{Q}_{\text {min }}$} & \multicolumn{2}{|c|}{$\mathrm{RRC}\left(\mathrm{Q}_{\max } / \mathrm{Q}_{\min }\right)$} & \multicolumn{2}{|c|}{ Ground Water } \\
\hline & & $\mathrm{Mm}$ & KAT & $\Delta(\%)$ & (tons/day) & $\Delta(\%)$ & $\mathrm{m}^{3} / \mathrm{sec}$ & $\Delta(\%)$ & $\mathrm{m}^{3} / \mathrm{sec}$ & $\Delta(\%)$ & Score & $\Delta(\%)$ & $\mathrm{mm}$ & $\Delta(\%)$ \\
\hline Existing & 1873 & 575 & 0,31 & & 47.966 & & 511,8 & & 2,6 & 198 & 211 & & & \\
\hline Scenario 1 & 1873 & 487 & 0,26 & -15 & 32.686 & -32 & 493,1 & -4 & 3,3 & 27 & 148 & -25 & 218 & 3 \\
\hline Scenario 2 & 1873 & 400 & 0,21 & -30 & 11.422 & -76 & 480,0 & -6 & 4,4 & 69 & 109 & -45 & 279 & 32 \\
\hline Scenario 3 & 1873 & 515 & 0,27 & -10 & 33.915 & -29 & 510,3 & 0 & 3,3 & 27 & 155 & -22 & 204 & -3 \\
\hline Scenario 4 & 1873 & 393 & 0,21 & -32 & 8.154 & -83 & 457,0 & -11 & 5,0 & 92 & 91 & -54 & 240 & 14 \\
\hline Scenario 5 & 1873 & 308 & 0,16 & -46 & 2.510 & -95 & 431,3 & -16 & 6,7 & 158 & 65 & -67 & 379 & 80 \\
\hline
\end{tabular}

Remarks: AFC = Annual Flow Coefficient; $\mathrm{Q}_{\max }=$ debit maximum; $\mathrm{Q}_{\min }=$ debit minimum; $\mathrm{RRC}=$ River Regime Coefficient

Compare with the existing, Scenario 1 would decrease the surface flow in $15 \%$, the decreased of sediment discharge was $32 \%$, the decreased of maximum river discharge was $4 \%$, the increased of minimum river discharge was $27 \%$, the decreased of $\mathrm{Q}_{\max }-\mathrm{Q}_{\min }$ ratio was $25 \%$ and the increased of ground water was $3 \% . \mathrm{Q}_{\max } / \mathrm{Q}_{\min }$ score in the amount of 148 , still categorized into a high score. Positive impact score toward the improvement of Ciujung Watershed is 6, ranked 4th out of five scenarios. Land area that which get management improvement is in the lowest rank compared with other scenarios, which is only 17.3333 ha or $12 \%$ from the Ciujung Watershed total area. One of the small effect of the improvement in the Scenario 1 perhaps due to small area which involved in management improvement.

Toward the existing condition, Scenario 2 would decrease the surface flow in $30 \%$, the decreased of sediment discharge was $76 \%$, the decreased of maximum river discharge was $6 \%$, the increased of minimum river discharge was $69 \%$, the decreased of $\mathrm{Q}_{\max }-\mathrm{Q}_{\min }$ ratio was $45 \%$ and the increased of ground water was $33 \% . \mathrm{Q}_{\max } / \mathrm{Q}_{\min }$ score in the amount of 109 is categorized into a high score. Positive impact score toward the improvement of Ciujung Watershed is 11, ranked 2nd out of five scenarios. Scenario 2 would be applied to improve a land management for 42.946 ha area or $30 \%$ from the total area in Ciujung Watershed.

Scenario 3 affected the improvement of existing condition. The reservoir contributed to reducing the surface runoff, to increasing the water retention, to enhance collecting and storing the water which can be used to increase the supply of water for agriculture and to im- proving watershed quality, especially shown through the decreasing of RRC and AFC parameters of the watershed [18]. Scenario 3 could only decreased the surface flow by $10 \%$, decreased sediment discharge by $29 \%$, almost did not reduced the maximum river discharge, increased the minimum river discharge by $27 \%$, decreased $\mathrm{Q}_{\max }-\mathrm{Q}_{\min }$ ratio by $45 \%$ and even the decreased the ground water was $3 \% . \mathrm{Q}_{\max }-\mathrm{Q}_{\min }$ ratio score in the amount of 155 is categorized into a high score. Positive impact score toward the improvement of Ciujung Watershed Area is 4, ranked 5th out of five scenarios. Area in the Scenario 3 which will be getting a management improvement is 40.202 ha area or $28 \%$ from the total area in Ciujung Watershed.

Ciujung Watershed area which will be getting management improvement using Scenario 4 is 47.954 ha or $34 \%$ from the total area. Scenario 4 could decreased the surface flow by $32 \%$, decreased sediment discharge by $84 \%$, decreased maximum river discharge by $11 \%$, increased minimum river discharge by $92 \%$, decreased Qmax-Qmin ratio by 54\% and would only be able to increase ground water in 14\%. Qmax-Qmin ratio score in the amount of 91 is still categorized into a high score. Positive impact score toward the improvement of Ciujung Watershed Area is 11, ranked 3rd out of five scenarios. Even though Scenario 4 and Scenario 3 have same score, Scenario 4 needs bigger management improvement, and then Scenario 4 has lower rank than Scenario 2.

Scenario 5 is the best scenario than the other scenarios. However, land management improvement in Scenario 5 is the widest compared with four scenarios, the area is 66.390 ha or $47 \%$ from total area in Ciujung Watershed. 
Scenario 5 could decreased the surface flow by $30 \%$, decreased sediment discharge by $95 \%$, decreased maximum river discharge by $16 \%$, increased minimum river discharge by $158 \%$, decreased $\mathrm{Q}_{\max }-\mathrm{Q}_{\min }$ ratio by $67 \%$ and increased ground water in $80 \%$. $\mathrm{Q}_{\max }-\mathrm{Q}_{\min }$ ratio score in the amount of 65 is categorized into a moderate score. Positive impact score toward the improvement of Ciujung Watershed Area is 16, ranked 1st out of five scenarios.
The five selected scenarios are still not being able to obtain a $\mathrm{Q}_{\max }-\mathrm{Q}_{\min }$ ratio lower than 20 , the value limits commonly used to indicate that watershed quality were good. Score calculation had been measured to find the effect from every watershed quality improvement effort through five scenarios as a whole or in aggregate as presented in the Table 6.

TABLE 6

POSITIVE EFFECT SCORE TOWARD THE IMPROVEMENT OF QUALITY PARAMETERS IN CIUJUNG WATERSHED AREA

\begin{tabular}{cccccccccc} 
Scenario & \multicolumn{2}{c}{ AFC } & \multicolumn{2}{c}{ Sediment Discharge } & \multicolumn{2}{c}{ RRC } & Ground Water & Total & Rangking \\
\cline { 2 - 7 } & $\Delta(\%)$ & Skor & $\Delta(\%)$ & Skor & $\Delta(\%)$ & Skor & $\Delta(\%)$ & Skor & Skor
\end{tabular}

\section{Existing}

Scenario 1

Scenario 2

$\begin{array}{lll}-15 & +1 & -32\end{array}$

$$
+2
$$

$+4$

Scenario 3

$-30$

$+2 \quad-76$

$-10$

$+1 \quad-29$

$+2$

Scenario 4

$\begin{array}{lll}-32 & +2 & -83\end{array}$

$+5$

Scenario 5

$\begin{array}{llll}-46 & +3 & -95 & +5\end{array}$

-25
-45
-22
-54
-67

$\begin{array}{ll}+2 & 3 \\ +3 & 32 \\ +2 & -3 \\ +3 & 14 \\ +4 & 80\end{array}$

$\begin{array}{lll}+1 & +6 & 4 \\ +2 & +11 & 2 \\ -1 & +4 & 5 \\ +1 & +11 & 3 \\ +4 & +16 & 1\end{array}$

From the simulation results, Scenario 5 is the most effective scenario which can improve the condition of Ciujung Watershed. However, scenario can be entitled as the best scenario considering the various aspects or factors and the way to deal with various limitations in implementing it. Scenario 5 required the application a lot of combination of soil and water conservation and lands management improvement area by 66.390 ha, the largest area at the highest cost among the five scenarios.

In facilitating to choose the best scenario by considering various factors, then it is necessary to examine the advantages and disadvantages from the application of each scenario that can be seen on the Table 7 .

TABLE 7

SOME ADVANTAGES AND DISADVANTAGES FROM THE APPLICATION OF EACH SCENARIO

\begin{tabular}{|c|c|c|c|c|}
\hline Scenario & LMIPA (ha) & Score* & Advatages & Disadvantages \\
\hline Scenario 1 & 17.333 & +6 & Cheapest & Long run improvement effect \\
\hline Scenario 2 & 42.946 & +11 & $\begin{array}{l}\text { Cheap Increased agriculture income } \\
\text { Rather big improvement effect }\end{array}$ & Long run improvement effect \\
\hline Scenario 3 & 40.202 & +4 & Cheap Increased agriculture income & Long run improvement effect \\
\hline Scenario 4 & 47.954 & +11 & $\begin{array}{l}\text { Rather big improvement effect } \\
\text { Short-term improvement effect }\end{array}$ & Expensive \\
\hline Scenario 5 & 66.390 & +16 & $\begin{array}{l}\text { Biggest improvement effect Short- } \\
\text { term improvement effect }\end{array}$ & $\begin{array}{l}\text { Most expensive Short-term improve- } \\
\text { ment effect }\end{array}$ \\
\hline
\end{tabular}

\%LMIPA = Land Management Improvement Plan Area * obtained from various scenario effect toward the surface flow, river discharge, sediment discharge and the addition of ground water (see Table 5)

Scenario 2 and Scenario 4 obtained similar watershed quality improvement score. However, considering the fact that Scenario 2 required cheaper financial plan of soil and water conservation techniques and involving smaller area improvement, then Scenario 2 is more appropriate to choose rather than Scenario 4. Scenario 2 is an optimal scenario if the cost, effectiveness and efficiency are the main considerations. 


\section{CONCLUSION}

During 2006 to 2011, forest area and tree plantation reduced by as much 3164,6 ha and the agriculture and plantation area increased by as much 2930,6 ha. Perhaps, this land use change is one of the ultimate causes in decreasing of Ciujung Watershed quality, which showed by AFC in $31 \%$ score, RRC was 198 and sediment discharge was 47.966 tons per day.

From the simulation result, Scenario 5 give a greatest quality improvement effect in Ciujung Watershed, meanwhile, Scenario 2 is the most optimal. All scenarios have not been able to reduce RRC scores under 20 to be categorized as good watershed quality.

\section{REFERENCES}

[1] G. Dunjó, G. Pardini, and M. Gispert, "The role of land use-land cover on runoff generation and sediment yield at a microplot scale, in a small mediterranean catchment," Journal of Arid Environments, vol. 57, no. 2, pp. 239-256, 2004. doi: http://doi.org/10.1016/S0140-1963(03)00097-1

[2] F. K. Maalim, A. M. Melesse, P. Belmont, and K. B. Gran, "Modeling the impact of land use changes on runoff and sediment yield in the Le Sueur watershed, Minnesota using GeoWEPP," Catena, vol. 107, pp. 35-45, 2013. doi: http://doi.org/10.1016/j. catena.2013.03.004

[3] L. Qiao, C. B. Zou, R. E. Will, and E. Stebler, "Calibration of SWAT model for woody plant encroachment using paired experimental watershed data," Journal of Hydrology, vol. 523, pp. 231-239, 2015. doi: http://doi.org/10.1016/j.jhydrol.2015.01.056

[4] L. M. Rachman, "Can the fluctuation of River Regime Coefficient (RRC) be used as an indication of fluctuations in the Quality of Watersheds (QoW)?" in Proceedings of the National Seminar on Integrated Watershed Management Towards the Preservation of Environmental Functions and Community Welfare, Sebelas Maret University, Surakarta, Indonesia, 2018.

[5] L. M. Rachman, "Technical development to assess soil health using soil health index in Indonesia," Journal of Applied and Physical Sciences, vol. 4, no. 3, pp. 79-85, 2018. doi: https://doi.org/10. 20474/japs-4.3.1

[6] X. Wang, N. Kannan, C. Santhi, S. Potter, J. Williams, and J. Arnold, "Integrating APEX output for cultivated cropland with SWAT simulation for regional modeling," Transactions of the ASABE, vol. 54, no. 4, pp. 1281-1298, 2011.

[7] S. Sudaryono, "Integrated watershed management
(DAS), the concept of sustainable development," Jurnal Teknologi Lingkungan, vol. 3, no. 2, pp. 153-158, 2011.

[8] S. Arsyad, Soil and water conservation. PT Penerbit IPB Press, 2009.

[9] K. Kustamar, E. Hargono, and B. Subakti, "Flood control strategy in solid residential area," Buletin Utama Teknik, vol. 14, no. 1, pp. 1-5, 2018.

[10] J. G. Arnold, D. N. Moriasi, P. W. Gassman, K. C. Abbaspour, M. J. White, R. Srinivasan, C. Santhi, R. Harmel, A. Van Griensven, M. W. Van Liew et al., "Swat: Model use, calibration, and validation," Transactions of the ASABE, vol. 55, no. 4, pp. 1491-1508, 2012. doi: http://doi.org/10.13031/ 2013.42256

[11] J. Arnold, J. Kiniry, R. Srinivasan, J. Williams, E. Haney, and S. Neitsch, "Soil and water assessment tool input/output file documentation version 2009," Texas, TX: Texas Water Resources Institute, Tech. Rep., 2011.

[12] L. Li, L. Zhang, J. Xia, C. J. Gippel, R. Wang, and S. Zeng, "Implications of modelled climate and land cover changes on runoff in the middle route of the south to north water transfer project in China," Water Resources Management, vol. 29, no. 8, pp. 2563-2579, 2015.

[13] R. Liu, P. Zhang, X. Wang, J. Wang, W. Yu, and Z. Shen, "Cost-effectiveness and cost-benefit analysis of BMPs in controlling agricultural nonpoint source pollution in China based on the SWAT model," Environmental Monitoring and Assessment, vol. 186, no. 12, pp. 9011-9022, 2014. doi: http: //doi.org/10.1007/s10661-014-4061-6

[14] M. Yusuf, B. Firuza, and O. Khairulmaini, "Variation in soil physiochemical properties at different land use sites in Northeastern Nigeria," International Journal of Applied and Physical Sciences, vol. 3, no. 1, pp. 26-34, 2017. doi: https: //doi.org/10.20469/ijaps.3.50004-1

[15] P. Phomcha, P. Wirojanagud, T. Vangpaisal, and T. Thaveevouthti, "Modeling the impacts of alternative soil conservation practices for an agricultural watershed with the SWAT model," Procedia Engineering, vol. 32, pp. 1205-1213, 2012.

[16] U. Chaube, S. Suryavanshi, L. Nurzaman, and A. Pandey, "Synthesis of flow series of tributaries in upper Betwa basin," International Journal of Environmental Sciences, vol. 1, no. 7, pp. 1459-1475, 2011.

[17] C. Santhi, J. G. Arnold, J. R. Williams, W. A. Dugas, R. Srinivasan, and L. M. Hauck, "Validation of the 
swat model on a large rwer basin with point and nonpoint sources 1," JAWRA- Journal of the American Water Resources Association, vol. 37, no. 5, pp. 1169-1188, 2001.

[18] L. M. Rachman, "Contribution of embungs in increasing water supply for agriculture and improving the Quality of Watersheds (QoD)," in Proceedings of the National Seminar on Integrated Watershed Management Towards the Preservation of Environmental Functions and Community Welfare, Sebelas Maret University, Surakarta, Indonesia, 2018. 